BIOKEMISTRI 18(2):77-81 (December 2006)

Available online at http://www.bioline.org.br/bk and at

http://www.ajol.info/journals/biokem

Printed in Nigeria
An international journal published by the

?istos?

Oigerian Society for Ëxperimental Siology

\title{
Antioxidant activity of the exudate from Aloe barbadensis leaves in diabetic rats
}

\author{
Harrison U. NWANJO* \\ Department of Medical Laboratory Sciences, Imo State University, Owerri, Nigeria
}

Received 2 June 2006

MS/No BKM/2006/017, @2006 Nigerian Society for Experimental Biology. All rights reserved.

\begin{abstract}
The effects of the exudate of Aloe barbadensis leaves on oxidative stress and some antioxidant status of streptozotocin induced - diabetic rats were studied. There was significant reduction in scavenging enzymes like superoxide dismutase (SOD) activity and significant increase in signs of oxidative tissue damage, such as lipid peroxidation products (plasma MDA) in streptozotocin induced - diabetic rats. Treatment with Aloe barbadensis $(150 \mathrm{mg} / \mathrm{kg})$ increased antioxidant enzymes like SOD activities and significantly reduced lipid peroxidation products. This study shows that high blood sugar leads to increased oxidative stress and that exudates of Aloe barbadensis leaves possessed antioxidant activity as shown by increased scavenging SOD activity and decreases in lipid peroxidation products levels.
\end{abstract}

Keywords: Diabetes, Aloe barbadensis, oxidative stress, Antioxidant enzymes

* E-mail: harrisonnwanjo@yahoo.co.uk , Tel: 0803-3525389 


\section{INTRODUCTION}

Diabetes mellitus is a metabolic disease characterized by hyperglycaemia and glycosuria due to absolute or relative lack of insulin. Diabetes mellitus is considered a chronic disease, not yet curable by any known orthodox medicine.

Oxidative stress is reported to be increased in patients with diabetes mellitus ${ }^{1}$. Accumulating evidence suggests that oxidative cellular injury caused by free radicals contributes to the development of diabetes mellitus ${ }^{2}$. Reactive oxygen species generated in the cells are scavenged by antioxidant enzymes. Moreover diabetes also induces changes in the tissue content and activity of the antioxidant enzymes ${ }^{3}$.

Many minor components of foods, such as secondary plant metabolites, have been shown to alter biological processes, which may reduce the risk of chronic diseases in humans ${ }^{4}$. Aloe barbadensis miller (otherwise known as Aloe vera) is a perennial plant belonging to the family liliaceae and with its origin in the North Africa. Aloes have long been used all over the world for their various medicinal properties. Aloe vera is one of the plants considered to have a hypoglycemic effect and many diabetic subjects take the gel because of its hypoglycaemic effect $^{5}$. Aloe vera not only possesses hypoglycaemic activity but is hypotensive, hepatoprotective and also blood purifier ${ }^{6}$.

In view of the above consideration the present study was designed to investigate the protective effect of Aloe vera on plasma lipid peroxide and superoxide dismutase (SOD) activity, an antioxidant enzyme.

\section{MATERIALS AND METHODS}

\section{Plant material}

Fresh spiny leaves of Aloe vera were collected from aloe plant growing from the horticultural unit of Imo State University, Owerri. Botanical identify was kindly confirmed by Dr. C. I. Onuoha of Plant Science and Biotechnology Department of Imo State University, Owerri. A voucher specimen of the plant is deposited in Imo State University, Owerri.

\section{Preparation of the crude extract}

Fresh spiny leaves of Aloe barbadensis were collected and washed without squeezing to remove debris and dust particles. Large quantities of the leaves were cut open and the inside was collected or extracted, weighed and stored for use.

A measured volume of the extract $(80 \mathrm{ml})$ was put in a weighed evaporating dish. The dish containing $80 \mathrm{ml}$ of extract was evaporated to dryness by weight difference; the weight of the active ingredient in the $80 \mathrm{ml}$ of the extract (the solid residue ( $2.4 \mathrm{~g})$ referred to as extract) was determined. Appropriate concentrations of the extract were made in distilled water for experiments and expressed as $\mathrm{mg} / \mathrm{ml}$.

\section{Acute toxicity test}

The acute toxicity $\left(\mathrm{LD}_{50}\right)$ of the extract was estimated in 30 Albino rats by oral compulsion as described by Miller and Tainter ${ }^{7}$. In brief, the method involved the administration of 5 different doses of the extract to 5 groups of rats (6 rats per group). The number of deaths in each group within 24 hours was recorded. The $\mathrm{LD}_{50}$ was estimated from the graph of percentage (\%) mortality (converted to probit) against log-dose of the extract-probit 5 being $50 \%$.

\section{Phytochemical tests}

The chemical classes of constituent in the freshly prepared extract were detected using standard phytochemical reagents and procedures as described by Trease and Evans ${ }^{8}$.

In general, tests for the presence or absence of phytochemical compound using the above methods involve the addition of an appropriate chemical agent to the crude material in a test tube. The mixture is then shaken vigorously or gently as the case may be. The presence or absence of saponins, flavonoids, tannins, alkaloids etc. was observed.

\section{Animals}

Wistar albino rats weighing 150-200g were used in this study. All the rats were kept at room temperature in the animal room of College of Medicine and Health Science, Imo State University, Owerri. They were allowed free access to water and feed diet (product of Pfizer 
Nigeria Ltd.) throughout the period of the experiment.

Eighteen rats, included for the study, were divided into 3 groups, 2 were made diabetic by intraperitoneal injection of $65 \mathrm{mg} / \mathrm{kg}$ body weight of streptozotocin (STZ) (Sigma, St. Louis, MO, USA) dissolved in citrate buffer (0.01M, pH 4.5). Diabetes was confirmed by the determination of fasting blood glucose concentration on the third day post administration of STZ showing fasting blood glucose levels above $250 \mathrm{mg} / \mathrm{dl}$.

Body weight and fasting blood glucose levels of all the rats were determined before the start of the experiment. Rats were divided into the following groups.

Group 1: Control, given only the citrate buffer (0.01M, pH 4.5);

Group 2: $\quad$ Streptozotocin induced diabetic, made with a single dose of streptozotocin $(65 \mathrm{mg} / \mathrm{kg}$ body weight $)$ by intraperitoneal route;

Group 3: Diabetic rats treated with Aloe barbadensis $150 \mathrm{mg} / \mathrm{kg} /$ once a day, daily. Treatment was by oral compulsion.

After 4 weeks of treatment the body weight and fasting blood glucose of the animals were again determined. Blood was collected and transferred in an EDTA anticoagulated tube for plasma separation.

\section{Experimental and analytical procedure}

Twelve hours after the last treatment and after the last feed given, $4 \mathrm{ml}$ of blood was collected from all the rats. The blood collected was transferred onto an EDTA anticoagulated tube.
The anticoagulated blood was then centrifuged using Wisperfuge model 1384 centrifuge (Tamson, Holland) for $15 \mathrm{~min}$ to facilitate separation. The plasma thus obtained was used for malondialdehyde (MDA) (product of lipid peroxidation) estimation. Plasma MDA was measured by a thiobarbituric acid assay procedure $^{9}$, which was calibrated using $1,1,3,3$ - tetraethoxypropane (Sigma Chemicals, St. Louis, MO, USA) as a standard. Results were expressed as nanomoles of MDA per millimetre of serum.

The remaining packed RBCs were washed thrice with normal saline. Haemolysis was performed by pipetting out $1 \mathrm{ml}$ of washed red blood suspension in ice-cold distilled water. Erythrocyte ghosts were sedimented in a highspeed refrigerated centrifuge at $12000 \mathrm{rpm}$ for 40min. The cell content was separated out carefully and used for superoxide dismutase estimation $^{10}$.

\section{Statistical analysis}

The results were analyzed using Duncan Multiple range test. All data are expressed as mean \pm SD. Differences between groups were considered significant at $\mathrm{p}<0.05$.

\section{RESULTS}

Table 1 shows the results of the analysis, in which there was a significant increase $(\mathrm{p}<0.05)$ in fasting blood glucose and a comparative decrease $(p<0.05)$ in body weight when compared with the normal control. There was a slight increase in body weight and a significant decrease in fasting blood glucose in diabetic rats treated with Aloe barbadensis.

Table 1: The mean values of body weight and blood glucose in normal, diabetic and Aloe barbadensis treated diabetic rats. Values are expressed as mean \pm SD. $(n=6)$

\begin{tabular}{|l|l|l|l|l|l|}
\hline Body weight & $\begin{array}{l}\text { Mean initial } \\
\text { weight }(\mathrm{g})\end{array}$ & $\begin{array}{l}\text { Mean final } \\
\text { weight }(\mathrm{g})\end{array}$ & $\begin{array}{l}\text { Mean weight } \\
\text { gained }(\mathrm{g})\end{array}$ & \multicolumn{2}{|c|}{$\begin{array}{l}\text { Fasting Blood } \\
\text { glucose }(\mathrm{mg} / \mathrm{dl})\end{array}$} \\
\hline & & & & Initial & After 4weeks \\
\hline Normal Control & $136.32 \pm 9.8$ & $173.79 \pm 11.8$ & $38.6 \pm 2.2$ & $94.54 \pm 2.6$ & $97.42 \pm 2.6$ \\
\hline Diabetic control & $138.26 \pm 10.54$ & $122.48 \pm 8.5$ & $14.2 \pm 2.1 * *$ & $252.22 \pm 3.0 *$ & $261.42 \pm 5.6$ \\
\hline Treated diabetic rats & $137.8 \pm 11.8$ & $133.6 \pm 12.2$ & $5.5 \pm 2.23 * *$ & $255.56 \pm 7.2 *$ & $107.71 \pm 4.4$ \\
\hline
\end{tabular}


Table 2: The mean values of lipid peroxide and vitamins $\mathrm{E}$ and $\mathrm{C}$ in normal, diabetic and Aloe barbadensis treated diabetic rats. Values are expressed as mean \pm SD. $(n=6)$.

\begin{tabular}{|l|l|l|l|}
\hline & $\begin{array}{l}\text { Normal } \\
\text { control }\end{array}$ & $\begin{array}{l}\text { Diabetic } \\
\text { control }\end{array}$ & $\begin{array}{l}\text { Treated } \\
\text { diabetic rats }\end{array}$ \\
\hline $\begin{array}{l}\text { MDA } \\
(\mathrm{nmol} / \mathrm{ml})\end{array}$ & $3.63 \pm 0.94$ & $6.03 \pm 1.51 * *$ & $4.02 \pm 0.62$ \\
\hline $\begin{array}{l}\text { SOD } \\
(\mathrm{U} / \mathrm{mg} \text { protein }\end{array}$ & $84.3 \pm 2.14$ & $45.42 \pm 1.94 * *$ & $80.3 \pm 3.14$ \\
\hline$*$ Significantly different from normal control \\
$\begin{array}{l}\text { group ( } p<0.05) . * * \text { Significantly different from } \\
\text { normal control and treated diabetic rats } \\
(p<0.05)\end{array}$
\end{tabular}

In Table 2 there was a significant increase in lipid peroxide levels $(\mathrm{p}<0.05)$ in streptozotocin induced diabetic rats with respect to normal controls. It also shows a statistically significant decrease in lipid peroxide levels in diabetic rats treated with extract of Aloe barbadensis leaves. The activities of SOD were significantly higher in diabetic rats treated with extract of Aloe barbadensis leaves compared to diabetic control rats $(\mathrm{p}<0.05)$. There was no significant difference among the treated diabetic and normal groups but there was significant difference between diabetic and normal controls.

\section{DISCUSSION}

Traditional plant remedies have been used for centuries in the treatment of diabetes ${ }^{4}$, but only a few have been scientifically evaluated. Therefore, we investigated the effect of extract if Aloe barbadensis leaves on biomarkers of oxidative stress and the antioxidant enzyme (SOD) in diabetic rats.

Our data showed that the extract of this plant significantly lowered the level of glucose in streptozotocin induced diabetic rats. This finding is similar to the work reported previously by Okyar et $a l^{5}$.

The increase in plasma MDA concentrations (end product of lipid peroxidation) in streptozotocin-induced diabetic rats along with a significant decease in the antioxidant SOD activity are in conformation with previous reports documenting elevated serum lipid peroxide levels and diminished antioxidant status in diabetic subjects ${ }^{11}$. In this study, aloe supplementation results in suppressed free radical-induced oxidative damage. The superoxide dismutase (SOD) activity was increased in the aloe treated group and signs of oxidative tissue damage, such as lipid peroxide, were decreased. Can et al ${ }^{12}$ found similar results in the treatment of neonatal streptozotocininduced type 2 diabetic rats. Can and coworkers reported that treatment with aloe decreased damage to liver, increased glutathione and decreased lipid peroxidation. Reports of research indicating high blood sugar leads to increased oxidative stress and evidence of oxidative damage has been demonstrated in arterial samples from human diabetic subjects ${ }^{13}$. This damage is caused by reactive oxygen species that promote lipid peroxidation and play a serious role in the development of cardiovascular disease. In 2000, Singh and coworkers conducted an extensive study showing that oral dosing with aloe induced the phase II enzyme system (including SOD, catalase and glutathione peroxidase) of mice and significantly reduced lipid peroxidation ${ }^{14}$.

And finally, in 2002 at the International Aloe Science Council (IASC) Annual Conference, Vinson Joe presented evidence from a human chemical study $^{13}$, that the bioavailability of antioxidant supplement vitamins $\mathrm{C}$ and $\mathrm{E}$ was increased by over 200 percent when taken Aloe vera gel.

The decreased activity of antioxidant molecular along with elevated lipid peroxide levels in diabetic rats could probably be associated with oxidative stress and/or decreased antioxidant defense potential ${ }^{15}$. The reversal in their content following treatment may be due to decreased oxidative load. The Aloe barbadensis leaf extracts may also act by either directly scavenging the reactive oxygen metabolites, due to the presence of various antioxidant compounds ${ }^{16}$ or by increasing the synthesis of antioxidant molecules.

\section{REFERENCES}

1. Baynes, J.W. (1991) Role of oxidative stress in development of complications in diabetes. Diabetes 40: 405-412. 
2. Bambolkar, S. and Sainani, G.S. (1995) Evaluation of oxidative stress in diabetics with or without vascular complications. J. Asso. Phys. India 43: 10-12.

3. Genet, S., Kale, R.K. and Baquer, N. Z. (2002) Alterations in antioxidant enzymes and oxidative damage in experimental diabetic rat tissue; Effect of vanadate and fenugreek (Trigonella faenum graeoum). Mol. Cell. Biochem. 236: 7-12.

4. Ugochukwu, N. H., Babady, N. E., Cobourne, M. and Gasset, S. R. (2003) The effect of Gongronema latifolium extracts on serum lipid profiles and oxidative stress in hepatocytes of diabetic rats. J. Bioscience. 28: 1-5.

5. Okyar, A., Can, A., Akev, N., Baktir, G. and Sutlupinar, N. (2001) Effect of Aloe vera leaves on blood glucose level in type I and type II diabetic rat models. Phytopthera. Res. 15: $157-161$.

6. Tiwari, A.K. and Rao, M. (2002) Diabetes mellitus and multiple therapeutic approaches of phytochemicals: Present status and future prospects. Curr. Sci. 83:30-38.

7. Miller, L. C. and Tainter, M. L. (1944) Estimation of EC50 and its error by means of log-probit graph paper. Proc. Soc. Exp. Biol. Med. 57: 261-269.

8. Trease, G.E. and Evans, M.C. 91983) Textbook of pharmacognosy. $12^{\text {th }}$ edition Bailliere, Tindall, London, pp 343-383.
9. Albro, P.W., Corbelt, J.T. and Schroder, J.L. (1986) Application of the thiobarbiturate assay to the measurement of lipid products in microsomes. Chem. Biol. Interact.86: 185-194.

10. McCord, J.M. and Fridovich, I. (1969) SOD enzyme functions for erythrocuprein. J.Biol. Chem. 244: 6049-6055.

11. Oberley, L.W. (1988) Free radicals and diabetes. Free Radical Biol. Med. 5: 113-124.

12. Can, A., Akev, N. and Baktir, G. (2004) Effect of Aloe vera leaf Gel and pulp extracts on the liver in Type - II Diabetic Rats Models. Biol. Pharm. Bull. 82: 211-225.

13. Vinson, J., Kharrat, S., and Andreoli, E. (2002) Effect of Aloe vera preparations on the human bioavailability of vitamins $\mathrm{C}$ and $\mathrm{E}$. International Aloe Science Council (IASC) annual conference presentation.

14. Singh, M., Dhanalakshmi, E. and Rao, M. (2000) Chemomodulatory action of Aloe vera on the profiles of enzymes associated with carcinogen metabolism and antioxidant status regulation in Mice. Phytomedicine 28: 317-324.

15. Mahdi, A.A. (2002) Free radicals and other antioxidatants. A textbook of Biochemistry by S.P. Siagh, srd Edn. CBs Publishers and Distributors. New Delhi pp545-555.

16. Gupta, S.K. Prakash, J. and Srivastava, S. (2002) Validation of traditional claim of Tulsi, Ocimum Sanctum Linn. as a medicinal plant. Ind. J. Exp. Biol. 40:765-773. 